\title{
Bacterial bioaugmentation for improving methane and hydrogen production from microalgae
}

\author{
Fan Lü', Jiaqi Ji', Liming Shao ${ }^{3}$ and Pinjing $\mathrm{He}^{1,2,3^{*}}$
}

\begin{abstract}
Background: The recalcitrant cell walls of microalgae may limit their digestibility for bioenergy production. Considering that cellulose contributes to the cell wall recalcitrance of the microalgae Chlorella vulgaris, this study investigated bioaugmentation with a cellulolytic and hydrogenogenic bacterium, Clostridium thermocellum, at different inoculum ratios as a possible method to improve $\mathrm{CH}_{4}$ and $\mathrm{H}_{2}$ production of microalgae.

Results: Methane production was found to increase by $17 \sim 24 \%$ with the addition of $C$. thermocellum, as a result of enhanced cell disruption and excess hydrogen production. Furthermore, addition of $C$. thermocellum enhanced the bacterial diversity and quantities, leading to higher fermentation efficiency. A two-step process of addition of C. thermocellum first and methanogenic sludge subsequently could recover both hydrogen and methane, with a 9.4\% increase in bioenergy yield, when compared with the one-step process of simultaneous addition of C. thermocellum and methanogenic sludge. The fluorescence peaks of excitation-emission matrix spectra associated with chlorophyll can serve as biomarkers for algal cell degradation.
\end{abstract}

Conclusions: Bioaugmentation with C. thermocellum improved the degradation of C. vulgaris biomass, producing higher levels of methane and hydrogen. The two-step process, with methanogenic inoculum added after the hydrogen production reached saturation, was found to be an energy-efficiency method for hydrogen and methane production.

\section{Background}

Microalgae have enormous potential as a source for biofuel and bioenergy production due to their high photosynthetic efficiencies, high growth rates, and characteristics of not requiring external organic carbon supply. Anaerobic digestion of algal biomass to biogas containing methane or hydrogen is one of the most energy-efficient and environmentally beneficial technologies [1]. The process is highly dependent on both substrate degradability as well as environmental conditions which regulate the microbial activity [2].

Anaerobic digestion could be carried out on microalgal residues after lipid extraction [3-6] or directly on freshly collected algae. With regard to the latter, the resistance of

\footnotetext{
*Correspondence: solidwaste@tongji.edu.cn

${ }^{1}$ State Key Laboratory of Pollution Control and Resource Reuse, Tongji

University, Shanghai 200092, China

${ }^{2}$ Institute of Waste Treatment and Reclamation, Tongji University, Shanghai

200092, China

Full list of author information is available at the end of the article
}

the microalgal cell wall could be one of the limiting factors for cell digestibility $[7,8]$. The cell wall of some microalgal species such as Chlorella sp. and Scenedesmus sp. is known to contain recalcitrant cellulose [9], which could protect the microalgae against enzyme attack, thus restricting algal biodegradability $[3,10]$. Lakaniemi et al. [11] found that only approximately 50\% of Chlorella vulgaris biomass was degraded during methanogenic fermentation. Various mechanical (high-pressure homogenization, bead beating), physical (ultrasonication), thermal, and chemical (acids, bases, and oxidizing agents) pretreatment methods have been investigated to improve the digestion efficiency [3,8,12-14]. However, although these pretreatment technologies could enhance methane production from algae with thick cell wall, the energy cost of pretreatment is high. For example, the amount of energy consumed in heating and pretreatment was found to be higher than or equal to the corresponding energy gain from increased methane production $[3,15,16]$.

\section{Biomed Central}


Besides, the use of thermochemical pretreatment may also lead to a possible formation of inhibitory substances (e.g. furfurals) [17]. Enzymatic hydrolysis is a wellknown biological pretreatment process. Sander and Murthy [18] found that cell walls of mixed algae are susceptible to degradation by cellulase and lipase. Ehimen et al. [13] reported a pretreatment process of addition of a combined enzyme mixture and individual enzymes to the Rhizoclonium biomass prior to anaerobic digestion. The researchers observed that the enzymatic pretreatment led to greater methane conversions than the mechanical methods, and that the action of cellulase resulted in maximum methane yield, when compared with that of other enzymes. However, enzymes are usually only effective at the initial stage after addition and become inactive soon afterwards. Comparatively, living bacteria can continuously hydrolyze the materials through growth and proliferation. Nevertheless, appropriate bacterial species should be carefully selected to be effective for microalgae hydrolysis and be compatible with subsequent or synchronous anaerobic digestion.

Considering that cellulose contributes to the cell wall recalcitrance in the microalgae $C$. vulgaris, this study investigated bioaugmentation with a thermophilic, anaerobic, cellulolytic, and hydrogenogenic bacterium, Clostridium thermocellum, which is also available from cellulose-fed anaerobic digester [19], as a possible method to improve the degradation of $C$. vulgaris biomass to enhance the efficiency of methane and hydrogen production. To our best knowledge, the present study is the first report on improving $C$. vulgaris degradation by bioaugmentation using $C$. thermocellum.

\section{Results}

\section{Methane and hydrogen production}

As shown in Figure 1a, all of the observed cumulative methane production increased steadily after a short lag phase, and the plateau phase was reached at approximately 35 days. Gompertz modeling (Table 1) revealed that the highest methane yield from $2 \mathrm{~g} \mathrm{VS} / \mathrm{L}$ of $C$. vulgaris without $C$. thermocellum in Series 1 was $318 \mathrm{ml} / \mathrm{g}$ VS. There was a clear difference in methane production after addition of $C$. thermocellum. The highest methane yields for the inoculum ratios of $1 \%$, $5 \%$, and $10 \%$ of $C$. thermocellum were 376,388 , and $403 \mathrm{ml} / \mathrm{g} \mathrm{VS}$, respectively. Correspondingly, the maximum methane production rate was found to increase from 23.11 to $33.14 \mathrm{ml} / \mathrm{g} \mathrm{VS} /$ day, and the lag time was noted to increase from 0.83 to 3.61 days when the inoculum ratio of $C$. thermocellum was increased from $0 \%$ to $10 \%$. However, when the concentration of algal biomass was increased to $3 \mathrm{~g} \mathrm{VS} / \mathrm{L}$ in Series 2, the highest methane yield and maximum methane production rate were much lower than those noted for the corresponding treatment in Series 1 with the same inoculum ratio of $5 \%$ of C. thermocellum (Figure 1b). Nevertheless, when compared with the one-step treatment, in the twostep treatment of Series 2, the maximum methane production rate was increased by $9 \%$ and the lag time was decreased by 2.37 days.

Hydrogen is a key intermediate during anaerobic digestion as well as a product synthesized by C. thermocellum. Hence, in the enrichment cultures of Series 1 with mixed inoculum and in the one-step treatment of Series 2, hydrogen was accumulated in the first few days and then was rapidly consumed by methanogens (Figure 1c). Hydrogen production increased with the increase in the inoculum ratio of $C$. thermocellum. Comparatively, in the two-step treatment of Series 2, the hydrogen produced in the first step with only $C$. thermocellum was further consumed and reached a maximum plateau value of $53.4 \mathrm{ml} \mathrm{H}_{2} / \mathrm{g}$ VS after 5 days (Figure $1 \mathrm{~d}$ ), equivalent to $0.167 \mathrm{~mol} / \mathrm{mol}$ of the corresponding methane production in the second step.

\section{Production of ethanol and volatile fatty acids (VFAs)}

Ethanol and VFAs were noted to be the main products in the acidogenic hydrogen-producing fermentation. The addition of $C$. thermocellum resulted in rapid production of ethanol from the microalgae in the initial 3 days (Figure 2). In Series 1, the ethanol accumulated to a maximum concentration, increasing from 0 to $77 \mathrm{mg}$ carbon per liter, with the increasing $C$. thermocellum inoculum ratio from $0 \%$ to $10 \%$, and then was rapidly consumed (Figure 2c-f). In the two-step treatment of Series 2 with higher microalgae concentration, the ethanol concentration remained at 51-60 mg carbon per liter in the first step until granular sludge was added (Figure 2h). The levels of total VFAs also increased from 185 to $457 \mathrm{mg}$ carbon per liter with the increase in C. thermocellum inoculum ratio from $0 \%$ to $10 \%$. In all the treatments, acetate, propionate, and butyrate were the dominate metabolites. Acetate and butyrate accounted for more than $70 \%$ of the total VFAs before a shift towards acetate and propionate pathways after 10 days. In Series 2, treatments with higher proportion of algal biomass showed relatively high levels of VFAs (418 and $367 \mathrm{mg}$ carbon per liter), in which a significant level of isovalerate was detected (Figure 2g, h).

\section{Microalgal degradation and bacterial growth monitored by fluorescent method}

Algal cells contain specific fluorescent biochemical components (e.g. chlorophyll), and therefore exhibit different excitation-emission matrix (EEM) profiles [20]. In the present study, C. vulgaris was found to demonstrate specific EEM profiles (Figure 3a) with five distinct 

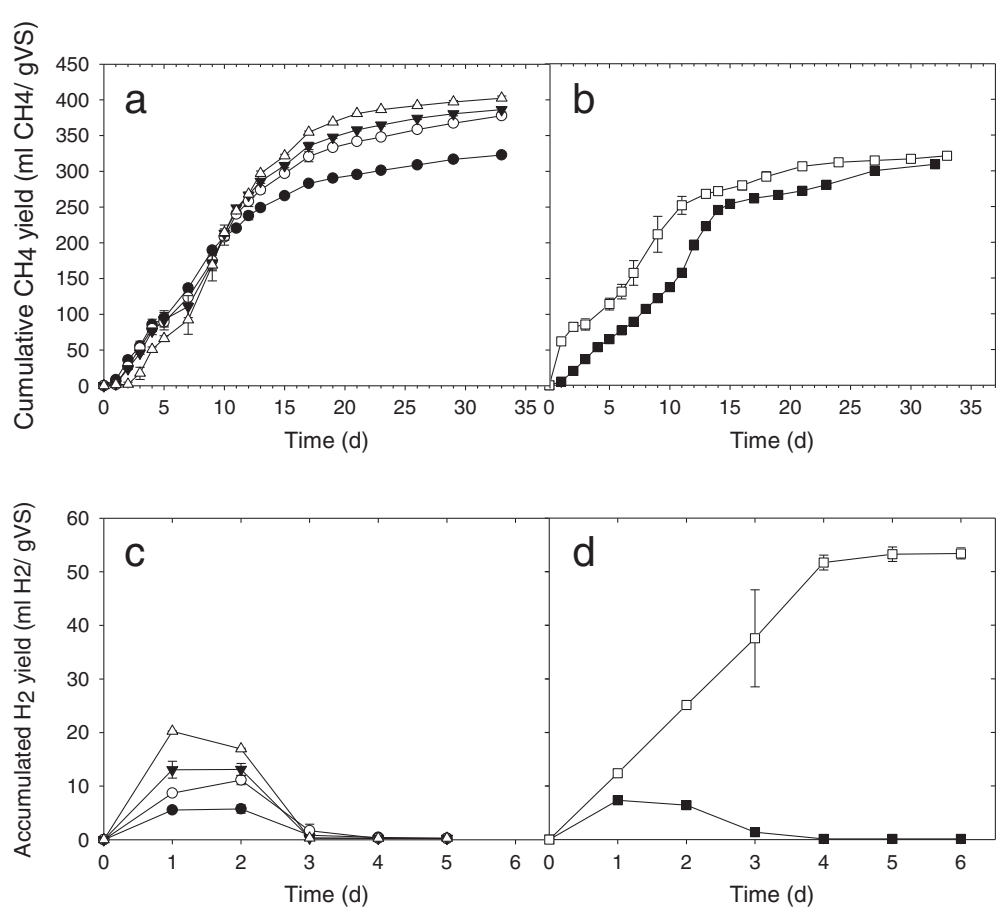

Figure 1 Methane and hydrogen production from C. vulgaris biomass. (a) cumulative methane yield in Series 1; (b) cumulative methane yield in Series 2; (c) accumulated hydrogen yield in Series 1; (d) accumulated hydrogen yield in Series 2, where inoculum ratios of $C$. thermocellum were $0 \%(\bullet), 1 \%(0), 5 \%(\boldsymbol{\nabla}), 10 \%(\Delta)$ and $(\mathbf{\bullet})$ for one-step experiment, ( $\square$ ) for two-step experiment. Error bar represents the data range of duplicate test.

fluorescent peaks (Ex/EM 400/660, 400/682, 400/625, $420 / 652$, and 650/662), which might be attributed to chlorophyll $a$ and $b[20,21]$. On the other hand, the EEM profile of $C$. thermocellum culture medium was completely different with two distinct peaks (Ex/EM 220/354, 270/354) (Figure 3b). Hence, the EEM profiles along the digestion process were collected to monitor the degradation of C. vulgaris, and were analyzed by parallel factor analysis (PARAFAC) method to resolve the EEM signals of the unknown samples from those of any overlapping and uncalibrated interferents. The core consistencies were $100 \%, 100 \%, 98.9 \%, 98.2 \%$, $74.5 \%, 64.5 \%$, and $7 \%$ for component numbers ranging from 1 to 7, respectively. Therefore, the optimal number of components was set to 4 for this model. The EEM contours of Components 1-4 are shown in Figure 3c-f, respectively. On comparing the basic EEM profiles of $C$. vulgaris and C. thermocellum culture medium, the following could be observed: Component 4 with the highest fluorescence was assigned to the distinct fluorophores from C. vulgaris; Component 1 was primarily contributed by $C$. thermocellum and partly by C. vulgaris; Component 3 was assigned to the soluble microbial products (SMP) generated from anaerobic digestion of the inoculated granular sludge; and Component 2 with low fluorescence intensity

Table 1 Calculated result using the modified gompertz equation for the cumulative methane production

\begin{tabular}{|c|c|c|c|c|c|}
\hline Series & Treatment $^{a}$ & $\begin{array}{l}\text { Ultimate methane yield } \\
\qquad P(\mathrm{ml} / \mathrm{g}-\mathrm{VS})\end{array}$ & $\begin{array}{l}\text { Maximum methane production } \\
\text { rate } R_{\max }(\mathrm{ml} / \mathrm{g} \mathrm{VS} \cdot \mathrm{d})\end{array}$ & $\begin{array}{l}\text { Lag phase } \\
\quad \lambda(\mathrm{d})\end{array}$ & $\mathrm{R}^{2}$ \\
\hline \multirow[t]{4}{*}{ Series 1} & $0 \%$ & $317.8 \pm 3.0$ & $23.11 \pm 0.84$ & $0.83 \pm 0.20$ & 0.996 \\
\hline & $1 \%$ & $375.4 \pm 4.4$ & $25.36 \pm 1.08$ & $1.62 \pm 0.25$ & 0.996 \\
\hline & $5 \%$ & $387.7 \pm 5.1$ & $27.38 \pm 1.32$ & $2.07 \pm 0.28$ & 0.994 \\
\hline & $10 \%$ & $402.8 \pm 3.8$ & $33.14 \pm 1.30$ & $3.61 \pm 0.21$ & 0.997 \\
\hline \multirow[t]{2}{*}{ Series 2} & One-step & $316.6 \pm 5.3$ & $20.36 \pm 1.21$ & $2.37 \pm 0.36$ & 0.990 \\
\hline & Two-step & $320.6 \pm 6.5$ & $22.38 \pm 1.78$ & $0 \pm 0.44$ & 0.986 \\
\hline
\end{tabular}

a: In series 1, Clostridium thermocellum was added by $0 \%, 1 \%, 5 \%$ and $10 \%$ (v/v) with $2 \mathrm{~g}$ VS/L of algal biomass and $3 \mathrm{~g}$ VS/L of methanogenic sludge. In series 2 , $5 \%$ C. thermocellum was added with $3 \mathrm{~g} \mathrm{VS} / \mathrm{L}$ of algal biomass and $2 \mathrm{~g}$ VS/L of methanogenic sludge for one-step. For two-step, $3 \mathrm{~g}$ VS/L of algal biomass was first incubated with $5 \%(\mathrm{v} / \mathrm{v})$ of $C$. thermocellum for hydrogen production and $2 \mathrm{~g}$ VS/L of methanogenic sludge was subsequently added to produce methane. The parameter standard error was obtained from the weighted regression. 

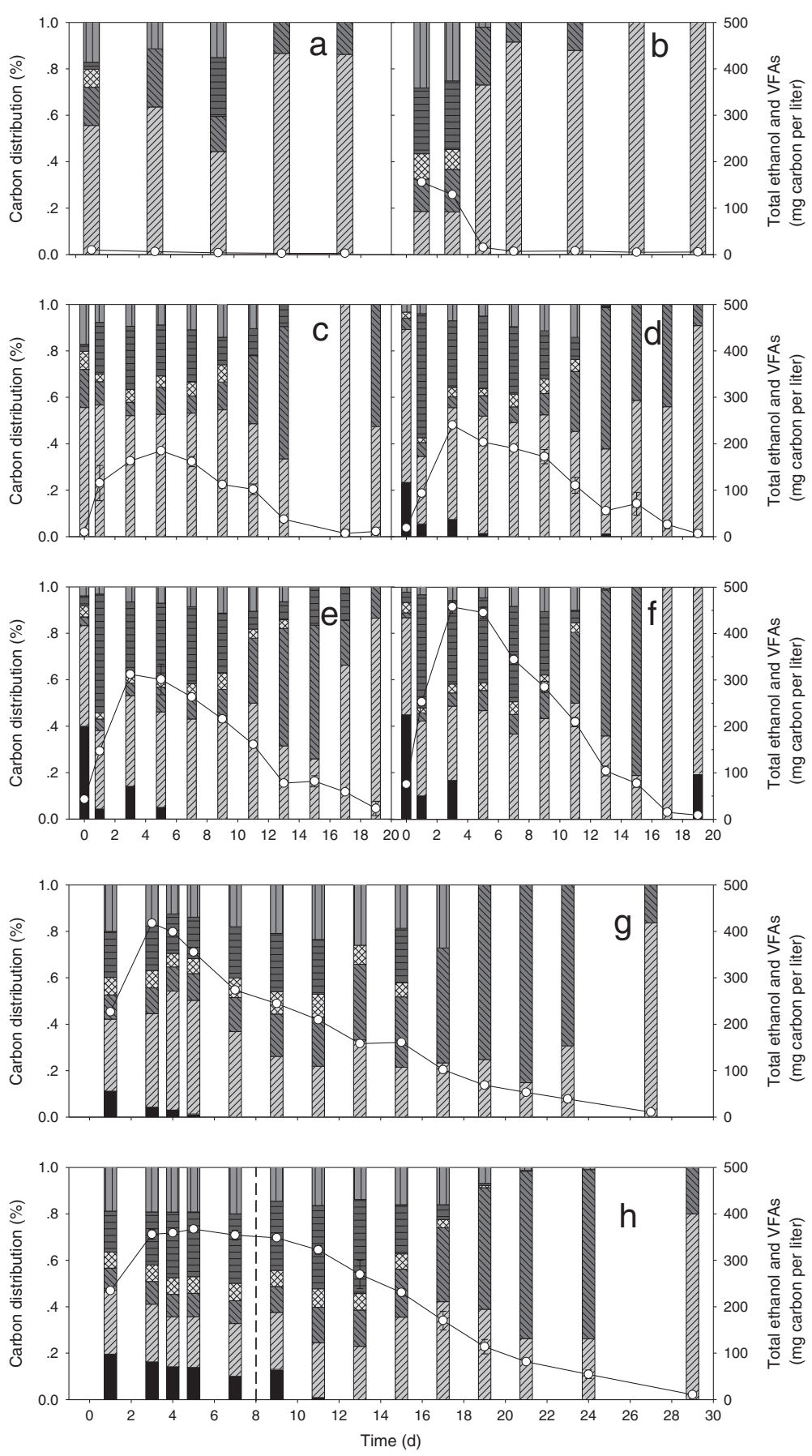

Figure 2 Ethanol and VFAs production. (a) The control with only granular sludge and without microalgae; (b) the control with granular sludge and $5 \%(\mathrm{v} / \mathrm{v})$ of C. thermocellum-containing culture medium; (c) $0 \%$, (d) $1 \%$, (e) $5 \%$ and (f) $10 \%(\mathrm{v} / \mathrm{v})$ of C. thermocellum in Series 1; (g) (h) onestep and two-step experiments in series2. ethanol, acetate, propionate, isobutyrate, butyrate, isovalerate and (o) total amount of ethanol and VFAs. The dashed in (h) showed the beginning of the second step.

was the systematic background of buffer solutions and instruments.

The scores of each PARAFAC component in different samples of Series 1 are presented in Figure 4. It can be noted that the scores of Component 1 representing $C$. thermocellum significantly increased with the $C$. thermocellum inoculum ratio, suggesting that the bacteria kept growing on the substrate of $C$. vulgaris during the initial 7 days. Component 3 representing SMP also had higher scores at higher $C$. thermocellum inoculum 

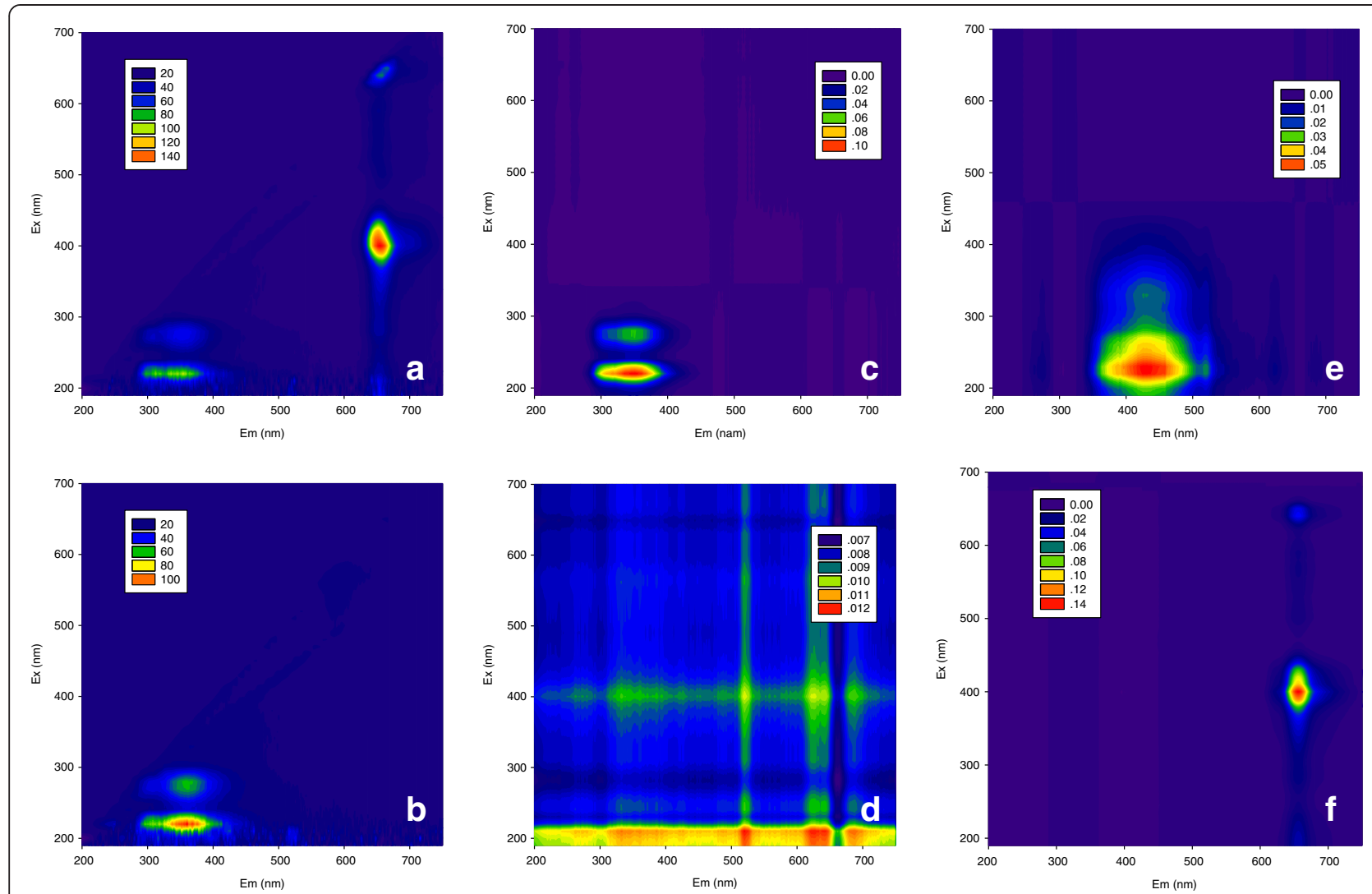

Figure 3 Excitation-emission matrix (EEM) profiles and four components extracted from parallel factor analysis (PARAFAC). (a) EEM profile of C. vulgaris microalgae; (b) EEM profile of C. thermocellum; (c) Component 1; (d) Component 2; (e) Component 3; (f) Component 4.
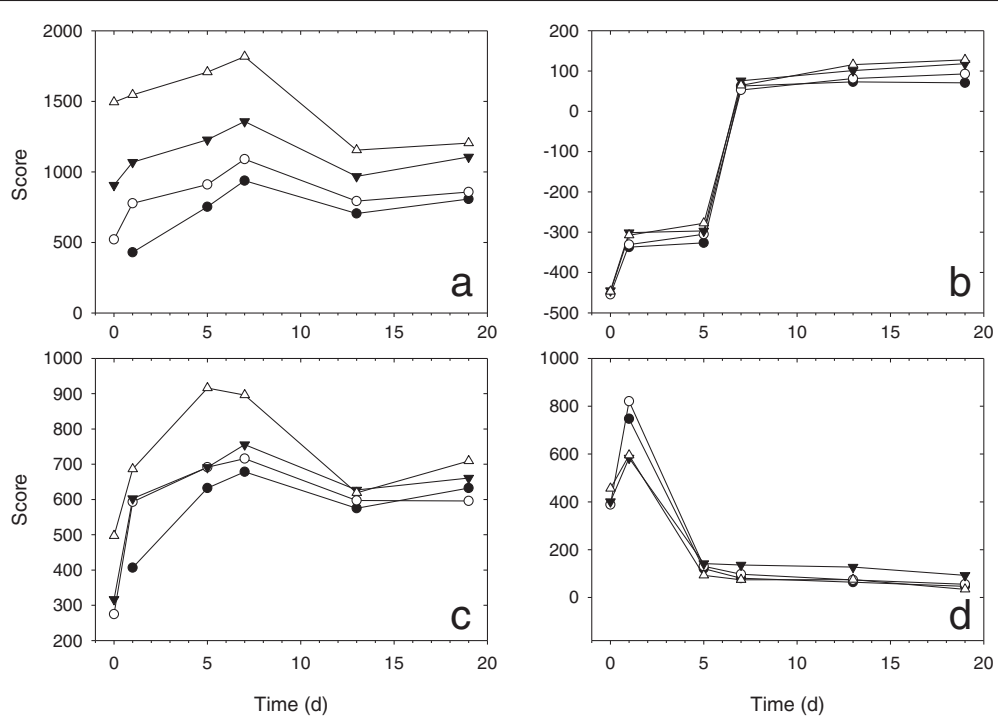

Figure 4 Scores of PARAFAC components in different samples from series 1. (a) Component 1; (b) Component 2; (c) Component 3; (d) Component 4 , where inoculum ratios of $\mathrm{C}$. thermocellum were $0 \%(\bullet), 1 \%(0), 5 \%(\mathbf{\nabla}), 10 \%(\Delta)$. 
ratio, implying that the growth of methanogenic inoculum was promoted by the addition of C. thermocellum. The scores of Component 4 representing microalgal fluorophores increased quickly on the first day and then decreased to a low value from Day 5 onwards, indicating rapid breakage and hydrolysis of the microalgal cell wall in $24 \mathrm{~h}$, resulting in the release of intracellular fluorophores. The released fluorophores were instantly fermented into low-molecular intermediates in 5 days, and the fermentation rate was higher in treatments with $5 \%$ and $10 \%$ C. thermocellum.

\section{Electron microscopic observation of microalgal cell degradation}

The C. vulgaris cells were observed under transmission electron microscopy (TEM). Samples taken from the treatment with $10 \%(\mathrm{v} / \mathrm{v})$ C. thermocellum at 0,7 , and 15 days are shown in Figure 5. The cells were about $2 \mu \mathrm{m}$ in diameter. The major portion of the cell was occupied by a C-shaped chloroplast made up of an array of photosynthetic lamellae. The initial cell was filled with cytoplasm and remained enclosed by the cell wall (Figure 5a, b). With the degradation of the cell, the cell wall was slightly damaged, while the organelles were nearly intact (Figure 5c, d). Subsequently, the organelles and cell walls were all broken into pieces (Figure 5e, f). TEM studies revealed that the cell wall played a significant role in resisting the attack of microorganisms. Likewise, TEM observations of other treatments exhibited a similar trend of $C$. vulgaris degradation, but the degradation rates were slightly lower.

\section{Automated ribosomal intergenic spacer analysis (ARISA)}

Shannon diversity index was used to analyze the ARISA profiles (Additional file 1: Figure S1-S4) to estimate the diversity of the microbial community (Figure 6) in the liquid and solid phase of the samples, respectively. For bacteria in liquid phase, the $H$ values of the treatments with $C$. thermocellum were significantly higher than those of the treatment without $C$. thermocellum during the initial 7 days and the $H$ value of the treatment with $5 \%$ inoculum ratio was the highest. In solid phase, the highest $H$ values were found for treatment with $10 \% C$. thermocellum, followed by those for treatment with $5 \%$ inoculum ratio. However, the $H$ values of treatments with $1 \%$ and $0 \% C$. thermocellum inoculum ratios were quite similar, and much lower than those of treatments with $10 \%$ and $5 \%$ inoculum ratios.

Similarly, for methanogens in liquid phase, the $H$ values of treatments with $C$. thermocellum were significantly higher than those of treatment without $C$. thermocellum. The $H$ value of treatment with $1 \% C$. thermocellum inoculum ratio was also the highest for methanogens in solid phase as in liquid phase, and showed a significant increase from Day 5 to Day 20. The $H$ values of treatment with $0 \%$ bacterial inoculum ratio were almost stable for the duration. However, the $H$ values of treatment with $5 \%$ and $10 \%$ inoculum ratios were close to those of treatment with $0 \%$ inoculum ratio during the first 12 days and then exhibited an obvious decrease.

\section{Discussion}

The cells of Chlorella are surrounded by a recalcitrant cellulosic cell wall, which encloses a parietal and cupshaped chloroplast with a pyrenoid $[9,22]$. While stained with multiple fluorochromes, the $C$. vulgaris cell wall consisted of $\beta$-polysaccharides could be clearly observed (Additional file 1: Figure S5 and Figure S6) [Note: cellulose belongs to $\beta$-polysaccharides]. If the microalgal biomass is not subjected to any cell disruption process, then the cell walls could be very resistant to hydrolysis, protecting the cells against the enzymes produced by the anaerobic consortium, and thus restricting cell biodegradability. C. thermocellum is an acetogenic, thermophilic, and anaerobic bacterium with a high rate of cellulose degradation and propensity to synthesize hydrogen. The present study found that C. thermocellum could utilize $C$. vulgaris as a substrate for growth (Figure 4). Furthermore, addition of C. thermocellum resulted in the production of higher levels of hydrogen (Figure 1), along with higher concentrations of ethanol, acetate, and butyrate (Figure 2). These results imply the contribution of $C$. thermocellum to algal cell degradation (Figure 5). The improved cell wall breakage resulted in the release of more organic matter, thus enhancing the diversity of bacteria in both suspension and granular phases, and the diversity of methanogens in the suspension phase (Figure 6). In addition, their quantities (as suggested by more SMP in Figure 4) were also ameliorated, favoring improvement in fermentation efficiency and process stability. Meanwhile, the hydrogen generated from $C$. thermocellum activity could promote the development of hydrogenotrophic methanogenesis, resulting in higher methane yield (Figure 1, Table 1) and an increase in the abundance of hydrogenotrophic methanogens, thus reducing the diversity of methanogens in granular phase (Figure 6). Therefore, anaerobic digestion of $C$. vulgaris biomass could be improved by the addition of $C$. thermocellum through enhanced cell disruption and excess hydrogen production.

The methane yield achieved from $C$. vulgaris degradation without bioaugmentation was $322 \mathrm{ml} \mathrm{CH}_{4} / \mathrm{g} \mathrm{VS}$, which is equivalent to $50 \%$ of the theoretical methane yield estimated by the carbohydrates, proteins, and lipid content of $C$. vulgaris and calculated according to Becker [23]. $\mathrm{CH}_{4}$ yield from microalgae was bound up 

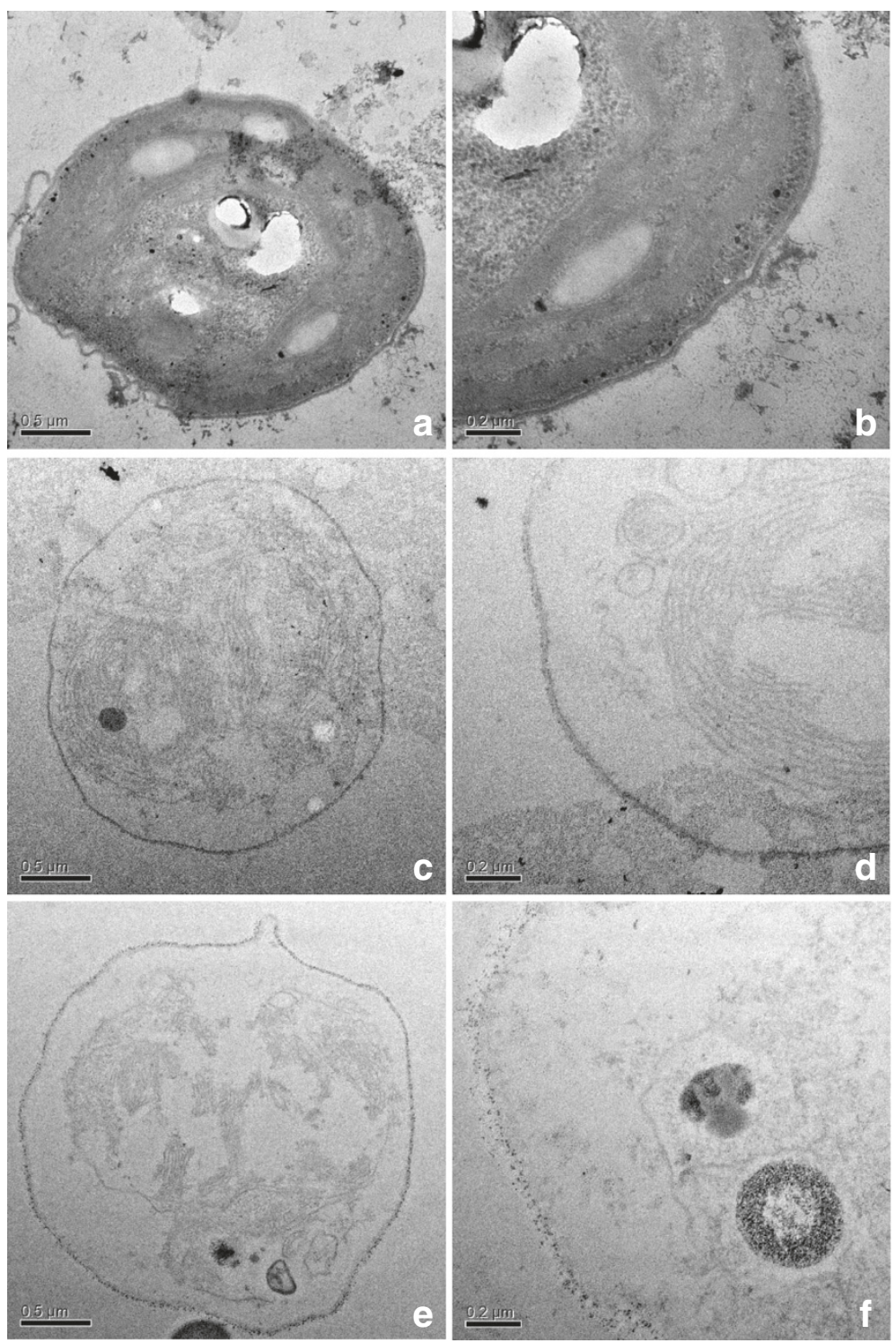

Figure 5 Transmission electron micrographs of $\boldsymbol{C}$. vulgaris during the cell degradation. (a, b) Early stage; (c, d) medium stage; and (e, $\mathbf{f})$ later stage. Scale bar $0.5 \mu \mathrm{m}(\mathbf{a}, \mathbf{c}, \mathbf{e}), 0.2 \mu \mathrm{m}(\mathbf{b}, \mathbf{d}, \mathbf{f})$.

with chemical composition of microalgal biomass and process parameters such as the bioreactor type and the digestion temperature [16]. Lakaniemi et al. [11] reported $286 \mathrm{ml} \mathrm{CH}_{4} / \mathrm{g}$ VS from C. vulgaris at $37^{\circ} \mathrm{C}$. Bruhn et al. [24] reported $271 \mathrm{ml} \mathrm{CH}_{4} / \mathrm{g}$ VS from macerated Ulva lactuca at $52^{\circ} \mathrm{C}$ and found that a decrease of the digestion temperature from $52^{\circ} \mathrm{C}$ to $37^{\circ} \mathrm{C}$ lowered the final methane yield by $7 \%$. Thus, the $\mathrm{CH}_{4}$ yield from C. vulgaris without bioaugmentation was comparable with previous results. With the addition of $C$. thermocellum, the methane production could be further increased by $17 \sim 24 \%$.

Unlike the one-step process, hydrogen accumulated in the cultures inoculated only with C. thermocellum in the first stage of the two-step treatment was not consumed by methanogens. As a result, both the bioenergy gases, hydrogen and methane, could be recovered. In Series 2, the hydrogen and methane yield from two-step treatment was 53 and $321 \mathrm{ml} / \mathrm{g}$ VS, respectively, equivalent to $13.4 \mathrm{~kJ} / \mathrm{g}$ VS of energy, which is $9.4 \%$ higher than the corresponding yield obtained from one-step treatment. When compared with the hydrogen yield reported in the literature, the yield obtained in the present study is of average magnitude. For example, Park et al. [25] reported a hydrogen yield of $28 \mathrm{ml} \mathrm{H}_{2} / \mathrm{g}$ dry weight from the microalgae Laminaria japonica pretreated by ball milling and heat treatment at $120^{\circ} \mathrm{C}$ for $30 \mathrm{~min}$, using anaerobic sewage sludge as an inoculum. Yang et al. [26] 

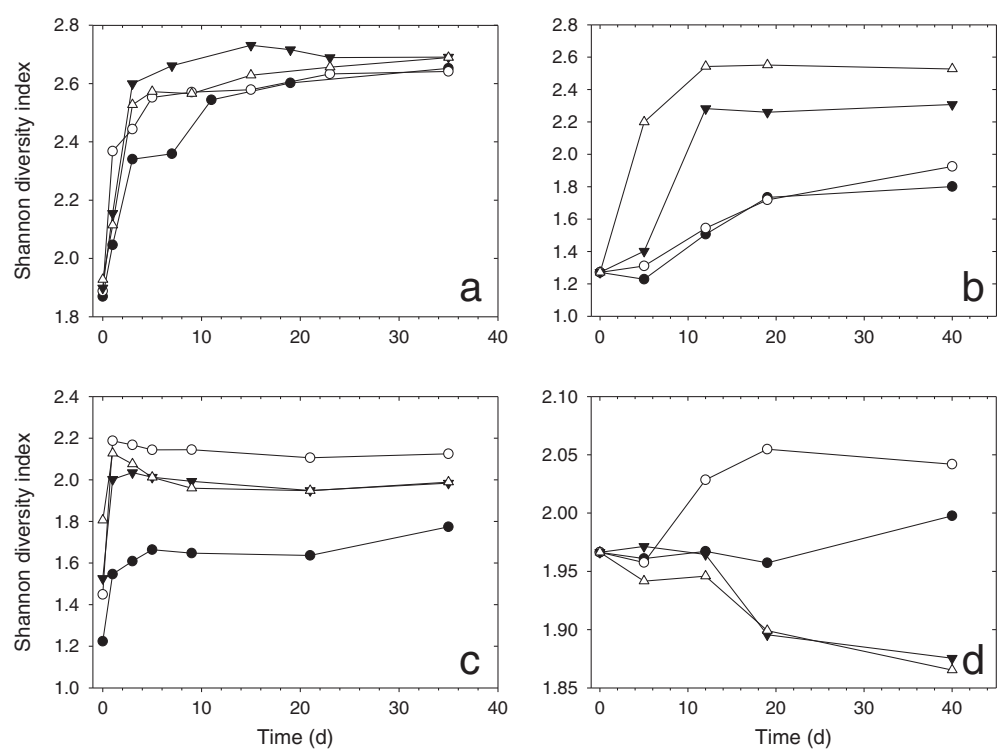

Figure 6 Shannon diversity. (a) Bacteria in liquid phase; (b) bacteria in solid phase; (c) methanogen in liquid phase; (d) methanogen in solid phase, where inoculum ratios of $C$. thermocellum were $0 \%(\bullet), 1 \%(0), 5 \%(\boldsymbol{\nabla}), 10 \%(\Delta)$.

achieved a hydrogen yield of $27.27 \mathrm{ml} \mathrm{H}_{2} / \mathrm{g}$ VS from lipid-extracted Scenedesmus biomass subjected to heat pretreatment at $95^{\circ} \mathrm{C}$ for $30 \mathrm{~min}$. Carver et al. [27] reported hydrogen yields of 82 and $114 \mathrm{ml} \mathrm{H}_{2} / \mathrm{g}$ VS from C. vulgaris using microalgae-associated bacteria and a thermophilic consortium at $60^{\circ} \mathrm{C}$, respectively, while Lakaniemi et al. [11] obtained a much lower hydrogen yield of $10.8 \mathrm{ml} \mathrm{H}_{2} / \mathrm{g}$ VS from the same algal biomass at $37^{\circ} \mathrm{C}$.

It should be noted that bioaugmentation with $C$. thermocellum made the anaerobic digestion system complex. The activity of this acidogenic phase bacteria might be coupled with a probable inhibition of the methanogens and/or a slower rate of acid intermediate consumption by the methanogenic process [4]. The longer lag time of $C$. thermocellum at a high inoculum ratio could probably be due to the need for the methanogens to alter their physiological state according to the new environment [28]. In addition to higher production of hydrogen, the two-step treatment presented shortest lag time and a comparable level of methane production, providing an energy efficiency method worthy of consideration. The proportions of algal biomass and methanogenic inoculum may also be an important parameter for methane production. The low proportion of granular sludge resulted in a much lower methane yield, longer lag time, and lower maximum methane production rate. This might be due to low methanogenic activity or the number of methanogens, which could result in the accumulation of VFAs. Therefore, proper methanogenic inoculum ratio relative to the amount of algal biomass and C. thermocellum should be considered.

\section{Conclusions}

Bioaugmentation with $C$. thermocellum improved the degradation of $C$. vulgaris biomass, producing higher levels of methane and hydrogen. However, the increases in methane yield were in the same order of magnitude with different inoculum ratios of $C$. thermocellum. The two-step process, with methanogenic inoculum added after the hydrogen production reached saturation, was found to be an energy-efficiency method for hydrogen and methane production. The fluorescence peaks of EEM spectra associated with chlorophyll can serve as biomarkers for algal cell degradation.

\section{Methods}

\section{Substrate and inoculum}

The microalgae C. vulgaris (strain ESP-6, Department of Chemical Engineering, National Cheng Kung University, Tainan, Taiwan) were grown photoautotrophically in Liquid Bold's Basal Medium (BBM) [29] with $0.1 \mathrm{vvm}$ $\mathrm{CO}_{2}\left(5 \% \mathrm{CO}_{2}\right.$ and $95 \% 0.45-\mu \mathrm{m}$ filtered air) sparging. Light was provided by 8000-10000 lux LED lights (WDTM-D35W, Widen Photodiode Technology Co., China). After 7 days of incubation, the microalgal biomass was harvested and concentrated by centrifugation at $3600 \times g$ for $15 \mathrm{~min}$. The solid concentrate was subjected to anaerobic digestion. The concentrated algal biomass contained $12.9 \%$ (on wet weight basis) of total solid (TS), 93.5\% (on dry weight basis) of volatile solid (VS), and 58,11 , and $14 \%$ (on dry weight basis) of proteins, lipids, and sugars, respectively.

C. thermocellum (strain DSM2360) was obtained from Leibniz Institute DSMZ-German Collection of 
Microorganisms and Cell Cultures. Fresh cultures were maintained by routinely transferring $5 \%(\mathrm{v} / \mathrm{v})$ inoculum into fresh medium containing $5 \mathrm{~g} / \mathrm{L}$ of absorbent cotton. Other compounds contained in the fresh medium included (per liter of distilled water): $\mathrm{KH}_{2} \mathrm{PO}_{4}, 0.50 \mathrm{~g} ; \mathrm{K}_{2} \mathrm{HPO}_{4} \cdot 3 \mathrm{H}_{2} \mathrm{O}$, 1.00 g; urea, 2.00 g; $\mathrm{MgCl}_{2} \cdot 6 \mathrm{H}_{2} \mathrm{O}, 0.50 \mathrm{~g} ; \mathrm{CaCl}_{2} \cdot 2 \mathrm{H}_{2} \mathrm{O}$, $0.05 \mathrm{~g} ; \mathrm{FeSO}_{4} \cdot 7 \mathrm{H}_{2} \mathrm{O}, 1.25 \mathrm{mg}$; morpholinopropane sulfonic acid, 10.00 g; resazurin, $1.00 \mathrm{mg}$; yeast extract, $6.00 \mathrm{~g}$; glucose, 5.00 g; cysteine- $\mathrm{HCl} \cdot \mathrm{H}_{2} \mathrm{O}, 1.00$ g. C. thermocellum was freshly harvested after 4 days of incubation when no more hydrogen production was detected.

Granular sludge, cultivated in a laboratory-scale (3.5 L) anaerobic sequenced batch reactor (ASBR), was added as the methanogenic inoculum. The ASBR was operated at $55^{\circ} \mathrm{C}$, and glucose and acetate (80\%:20\%, calculated as COD) were utilized as the feedstock at an organic loading rate of $2 \mathrm{~g} \mathrm{COD} /(\mathrm{L}$-day). The methanogenic sludge was taken after being acclimated for more than 50 days and rinsed with anaerobic preheated $\left(55^{\circ} \mathrm{C}\right)$ buffer solution to remove the residual carbon. The buffer solution was the same as that used in the subsequent batch experiments. The TS of the granular sludge was $11.1 \%(w / w)$ and the VS was $77.8 \%(w / w)$ of the TS.

\section{Experimental setup}

(1) Series 1: One-step methane production with different inoculum ratios of $C$. thermocellum

Batch experiments were conducted at $55^{\circ} \mathrm{C}$ with $2 \mathrm{~g}$ $\mathrm{VS} / \mathrm{L}$ of the algal biomass and $3 \mathrm{~g} \mathrm{VS} / \mathrm{L}$ of methanogenic sludge. The culture medium containing $C$. thermocellum was added at different inoculum ratios: $0 \%, 1 \%, 5 \%$, and $10 \%(\mathrm{v} / \mathrm{v})$. A control with only granular sludge and without microalgae was prepared to measure the endogenous activity of the sludge itself. Another control with granular sludge and culture medium containing $5 \%(\mathrm{v} / \mathrm{v})$ of $C$. thermocellum was set up to determine the methane production potential of the culture medium. The bottles were filled up to $500 \mathrm{ml}$ with buffer solution and flushed with nitrogen for $2 \mathrm{~min}$ to maintain anaerobic conditions. The composition of the buffer solution was as follows (per L): $1.0 \mathrm{~g}$ of $\mathrm{NH}_{4} \mathrm{Cl}, 0.4 \mathrm{~g}$ of $\mathrm{K}_{2} \mathrm{HPO}_{4} \cdot 3 \mathrm{H}_{2} \mathrm{O}$, $0.2 \mathrm{~g}$ of $\mathrm{MgCl}_{2} \cdot 6 \mathrm{H}_{2} \mathrm{O}, 0.08 \mathrm{~g}$ of $\mathrm{CaCl}_{2} \cdot 2 \mathrm{H}_{2} \mathrm{O}, 10 \mathrm{ml}$ of trace element solution, and $10 \mathrm{ml}$ of stock vitamin solution. The stock trace element and vitamin solutions were prepared according to Chen et al. [30].

(2)Series 2: Two-step co-production of hydrogen and methane

In the two-step experiment, $3 \mathrm{~g} \mathrm{VS} / \mathrm{L}$ of algal biomass was first incubated with $5 \%(\mathrm{v} / \mathrm{v})$ of $C$. thermocellum containing culture medium at $55^{\circ} \mathrm{C}$ for 7 days in $500-\mathrm{ml}$ buffer solution, as mentioned earlier, for hydrogen production. Subsequently, $2 \mathrm{~g} \mathrm{VS} / \mathrm{L}$ of methanogenic sludge was added to produce methane. As a reference, a onestep experiment with the same amount of algal biomass, granular sludge, and $5 \%(\mathrm{v} / \mathrm{v})$ of $C$. thermocellum containing culture medium was set up. Furthermore, a control with granular sludge and $5 \%(\mathrm{v} / \mathrm{v})$ of $C$. thermocellum containing culture medium, similar to that used in Series 1, was also included in this series. Two different inoculum to substrate ratios (methanogenic sludge to microalgal biomass: $3: 2$ in series 1 and 2:3 in series 2) were introduced to investigate the influence of inoculum to substrate ratio. All the experiments were carried out in duplicate and the results were expressed as means.

\section{Analysis of gaseous and liquid samples}

Gas production was measured by manometric methods. The pressure in the headspace of the serum bottles was measured by a Testo 512 pressure meter (Testo, Germany). The concentrations of hydrogen, methane, and carbon dioxide in the biogas were analyzed using a gas chromatograph (GC112A, Shanghai Precision \& Scientific Instrument Co., China) equipped with a thermal conductivity detector (TCD). The gas volumes were corrected to standard temperature and pressure conditions (STP: $0^{\circ} \mathrm{C}$ and $1013 \mathrm{kPa}$ ). Methane production from the culture medium and methanogenic sludge was deducted in the reported data. Gompertz modeling (Eq.1) was used according to Lü et al. [31] to fit the curve of the cumulative methane production, and the values of three parameters $\left(P, R_{\max }\right.$, and $\left.\lambda\right)$ were determined.

$$
M(t)=P \cdot \exp \left\{-\exp \left[\frac{R_{\max } \cdot e}{P}(\lambda-t)+1\right]\right\}
$$

$M(t)$ is the cumulative methane production $(\mathrm{ml} / \mathrm{g}$ VS added) at time $t$ (days), $P$ is the highest methane yield $(\mathrm{ml} / \mathrm{g} \mathrm{VS}), R_{\max }$ is the maximum methane production rate $(\mathrm{ml} / \mathrm{g} \mathrm{VS} /$ day), and $\lambda$ is the lag phase (days). Lag phase refers to the initial adaptive phase, during which methane production remains relatively constant prior to rapid growth.

The liquid samples were centrifuged at $16,000 \times g$ for $10 \mathrm{~min}$. Subsequently, the supernatants were collected and analyzed for $\mathrm{pH}$, volatile fatty acids (VFAs), alcohols, dissolved organic carbon (DOC), total inorganic carbon (TIC), dissolved nitrogen (DN), and three-dimensional fluorescent intensity. The $\mathrm{pH}$ was tested with a $\mathrm{pHS}-2 \mathrm{~F}$ Digital Meter. The DOC, TIC, and DN were analyzed on a TOC-V $\mathrm{V}_{\mathrm{CPH}}$ Analyzer (Shimadzu, Japan). The concentrations of VFAs (including acetic, propionic, isobutyric, 
butyric, and isovaleric acids) and alcohols in the supernatant were determined using an Agilent $6890 \mathrm{~N}$ gas chromatography (GC) system equipped with a flame ionization detector (FID). The fluorescence excitationemission matrixes (EEM) were recorded for the supernatant in a 10-mm quartz cuvette in a Varian Cary Eclipse fluorometer (Agilent, Santa Clara, CA, USA). The emission was scanned from 220 to $750 \mathrm{~nm}$ at 2-nm intervals and $10-\mathrm{nm}$ bandwidth, while the excitation was produced with a Xenon flash lamp in 10-nm bandwidth at 10-nm intervals from 200 to $700 \mathrm{~nm}$. The EEM signals were processed and subjected to parallel factor analysis (PARAFAC), as described in the study by Lu et al. [32].

\section{Transmission electron microscopy observation of the microalgal cell}

The cells of C. vulgaris were observed using transmission electron microscopy (TEM). Samples were prepared according to the procedure developed by Yamamoto et al. [33], and examined with a transmission electron microscope (JEM-1230, JEOL, Japan).

\section{Multiple fluorochrome staining of the microalgal cell and spectral microscopy observation}

The cells of $C$. vulgaris were stained successively by FITC for proteins, Con A for $\alpha$-polysaccharides and calcofour white for $\beta$-polysaccharides according to Chen et al.[34]. The samples were then examined with a Leica DMI 4000B spectral microscope imaging system.

\section{DNA manipulation}

Both the liquid samples and granules corresponding to different sampling dates were used for DNA extraction. The total DNA was extracted from the pellets using PowerSoil DNA isolation kit (MoBio Laboratories Inc., $\mathrm{CA}$ ), according to the manufacturer's protocol. The fingerprint technique of Automated Ribosomal Intergenic Spacer Analysis (ARISA) was used to monitor the microbial dynamics. The extracted DNA was amplified using primers $1389 \mathrm{~F}$ and $71 \mathrm{R}$ for archaea, and primers ITSF and ITSReub for bacteria, respectively. Polymerase chain reaction (PCR) and ARISA of the PCR product were carried out according to the method described by $\mathrm{Qu}$ et al. [35]. Shannon diversity index was used to analyze the ARISA profiles and $H$ value was calculated using the software PAlaeontological STatistics (PAST) version $2.17 \mathrm{~b}$, according to the procedure proposed by Hammer et al. [36].

\section{Additional file}

Additional file 1: Figure S1. ARISA profile of bacteria in liquid phase. The marks (e.g. "23") above represent the time of incubation, for example, "23" means the day 23 in the incubation. Figure S2 ARISA profile of bacteria in solid phase. The marks (e.g. "12") above represent the time of incubation, for example, "12" means the day 12 in the incubation. The profile marked with 0 represents the profile of the seed sludge, which was used in all the reactors at day 0 . Figure S3 ARISA profile of methanogens in liquid phase. The marks (e.g. "23") above represent the time of incubation, for example, "23" means the day 23 in the incubation. Figure S4 ARISA profile of methanogens in solid phase. The marks (e.g. "12") above represent the time of incubation, for example, "12" means the day 12 in the incubation. The profile marked with 0 represents the profile of the seed sludge, which was used in all the reactors at day 0 . Figure S5 The spectral microscope images of stained Chlorella vulgaris. a phase contrast photograph, $\mathbf{b}$ combined image of individual images in c-e, c spectral microscope image of a-polysaccharides (con A), d spectral microscope image of $\beta$-polysaccharides (calcofluor white), e spectral microscope image of protein (FITC). Figure S6 The spectral microscope images of stained Chlorella vulgaris cells and cell walls. a phase contrast photograph, b spectral microscope image of $\beta$-polysaccharides (calcofluor white).

\section{Abbreviations}

VFA: Volatile fatty acid; EEM: Excitation-emission matrix; PARAFAC: Parallel factor analysis; SMP: Soluble microbial products; TEM: Transmission electron microscopy; ARISA: Automated ribosomal intergenic spacer analysis; PCR: Polymerase chain reaction; DOC: Dissolved organic carbon; TIC: Total inorganic carbon; DN: Dissolved nitrogen; TS: Total solid; VS: Volatile solid.

\section{Competing interests}

The authors declare that they have no competing interests.

\section{Authors' contributions}

FL conceived the study, participated in microbial community analyses, parallel factor analyses, data interpretation and thoroughly reviewed the manuscript. JJ carried out the microalgae and biomass production and harvesting, anaerobic cultivations and all related analyses, microbial community analyses, data interpretation, and drafting and completion of the manuscript. LS participated in the design of the study and data interpretation, and thoroughly reviewed the manuscript. PH participated in the design of the study and data interpretation, and thoroughly reviewed the manuscript. All authors read and approved the final manuscript.

\section{Acknowledgements}

This research was partially sponsored by the National Basic Research Program of China (973 Program, No. 2012CB719801), the National Natural Science Foundation of China (No. 51178327; 21177096), the Innovation Program of Shanghai Municipal Education Commission (13ZZ030), the Shanghai Pujiang Program (No. 11PJ1409200), the Fundamental Research Funds for the Central Universities (No. 0400219195), and the State Key Laboratory of Pollution Control and Resource Reuse Foundation (PCRRY11008).

\section{Author details}

'State Key Laboratory of Pollution Control and Resource Reuse, Tongji University, Shanghai 200092, China. ${ }^{2}$ Institute of Waste Treatment and Reclamation, Tongji University, Shanghai 200092, China. ${ }^{3}$ Centre for the Technology Research and Training on Household Waste in Small Towns \& Rural Area, Ministry of Housing and Urban-rural Development of PR. China (MOHURD), Beijing, China.

Received: 5 April 2013 Accepted: 26 June 2013

Published: 1 July 2013

\section{References}

1. Hughes AD, Kelly MS, Black KD, Stanley MS: Biogas from Macroalgae: is it time to revisit the idea? Biotechnol Biofuels 2012, 5:86

2. Vandenbroucke $M$, Largeau C: Kerogen origin, evolution and structure. Org Geochem 2007, 38:719-833.

3. Sialve B, Bernet N, Bernard O: Anaerobic digestion of microalgae as a necessary step to make microalgal biodiesel sustainable. Biotechnol Adv 2009, 27:409-416. 
4. Ehimen EA, Sun ZF, Carrington CG, Birch EJ, Eaton-Rye JJ: Anaerobic digestion of microalgae residues resulting from the biodiesel production process. Appl Energ 2011, 88:3454-3463.

5. Ehimen EA, Connaughton S, Sun Z, Carrington GC: Energy recovery from lipid extracted, transesterified and glycerol codigested microalgae biomass. GCB Bioenergy 2009, 1:371-381.

6. Yang ZM, Guo RB, Xu XH, Fan XL, Luo SJ: Hydrogen and methane production from lipid-extracted microalgal biomass residues. Int Hydrogen Energ 2011, 36:3465-3470.

7. Afi L, Metzger P, Largeau C, Connan J, Berkaloff C, Rousseau B: Bacterial degradation of green microalgae: incubation of Chlorella emersonii and Chlorella vulgaris with Pseudomonas oleovorans and Flavobacterium aquatile. Org Geochem 1996, 25:117-130.

8. Chen $\mathrm{PH}$, Oswald WJ: Thermochemical treatment for algal fermentation. Environ Int 1998, 24:889-897.

9. Okuda K: Structure and phylogeny of cell coverings. J Plant Res 2002, 115:283-288.

10. Sánchez Hernández EP, Travieso Córdoba L: Anaerobic digestion of Chlorella vulgaris for energy production. Resour, Conserv Recy 1993, 9:127-132.

11. Lakaniemi AM, Hulatt CJ, Thomas DN, Tuovinen OH, Puhakka JA: Biogenic hydrogen and methane production from Chlorella vulgaris and Dunaliella tertiolecta biomass. Biotechnol Biofuels 2011, 4.

12. Jeon B-H, Choi J-A, Kim H-C, Hwang J-H, Abou-Shanab R, Dempsey B, Regan J, Kim J: Ultrasonic disintegration of microalgal biomass and consequent improvement of bioaccessibility/bioavailability in microbial fermentation. Biotechnol Biofuels 2013, 6:37

13. Ehimen EA, Holm-Nielsen JB, Poulsen M, Boelsmand JE: Influence of different pre-treatment routes on the anaerobic digestion of a filamentous algae. Renew Energ 2013, 50:476-480.

14. McMillan JR, Watson IA, Ali M, Jaafar W: Evaluation and comparison of algal cell disruption methods: microwave, waterbath, blender, ultrasonic and laser treatment. Appl Energ 2013, 103:128-134.

15. Yen HW, Brune DE: Anaerobic co-digestion of algal sludge and waste paper to produce methane. Bioresour Technol 2007, 98:130-134.

16. Lakaniemi $\mathrm{AM}$, Tuovinen $\mathrm{OH}$, Puhakka JA: Anaerobic conversion of microalgal biomass to sustainable energy carriers - a review. Bioresour Technol 2013, 135:222-231.

17. Taherzadeh MJ, Karimi K: Pretreatment of lignocellulosic wastes to improve ethanol and biogas production: a review. Int J Mol Sci 2008, 9:1621-1651.

18. Sander K, Murthy GS: Enzymatic degradation of microalgal cell walls. Reno, Nevada, USA: ASABE annual international meeting; 2009.

19. Lü F, Bize A, Guillot A, Monnet V, Madigou C, Chapleur O, Mazéas L, He PJ, Bouchez T: Metaproteomics of cellulose methanization under thermophilic conditions reveals a surprisingly high proteolytic activity. ISME J 2013. doi:10.1038/ismej.2013.120.

20. Simis SGH, Huot Y, Babin M, Seppala J, Metsamaa L: Optimization of variable fluorescence measurements of phytoplankton communities with cyanobacteria. Photosynth Res 2012, 112:13-30.

21. Erokhina LG, Shatilovich AV, Kaminskaya OP, Gilichinskii DA: The absorption and fluorescence spectra of the cyanobacterial phycobionts of cryptoendolithic lichens in the high-polar regions of Antarctica. Microbiology 2002, 71:601-607.

22. Phukan MM, Chutia RS, Konwar BK, Kataki R: Microalgae Chlorella as a potential bio-energy feedstock. Appl Energ 2011, 88:3307-3312.

23. Becker EW: Micro-algae as a source of protein. Biotechnol Adv 2007, 25:207-210.

24. Bruhn A, Dahl J, Nielsen HB, Nikolaisen L, Rasmussen MB, Markager S, Olesen B, Arias C, Jensen PD: Bioenergy potential of Ulva lactuca: Biomass yield, methane production and combustion. Bioresour Technol 2011, 102:2595-2604

25. Park Jl, Lee J, Sim SJ, Lee JH: Production of hydrogen from marine macroalgae biomass using anaerobic sewage sludge microflora. Biotechnol Bioprocess Eng 2009, 14:307-315.

26. Yang ZM, Guo RB, Xu XH, Fan XL, Luo SJ: Fermentative hydrogen production from lipid-extracted microalgal biomass residues. App/ Energ 2011, 88:3468-3472

27. Carver SM, Hulatt CJ, Thomas DN, Tuovinen $\mathrm{OH}$ : Thermophilic, anaerobic co-digestion of microalgal biomass and cellulose for $\mathrm{H}_{2}$ production. Biodegradation 2011, 22:805-814.
28. Cheong DY, Hansen CL: Feasibility of hydrogen production in thermophilic mixed fermentation by natural anaerobes. Bioresour Technol 2007, 98:2229-2239.

29. He PJ, Mao B, Shen CM, Shao LM, Lee DJ, Chang JS: Cultivation of Chlorella vulgaris on wastewater containing high levels of ammonia for biodiesel production. Bioresour Technol 2013, 129:177-181.

30. Chen CL, Macarie H, Ramirez I, Olmos A, Ong SL, Monroy O, Liu WT: Microbial community structure in a thermophilic anaerobic hybrid reactor degrading terephthalate. Microbiology 2004, 150:3429-3440.

31. Lü F, Hao L, Zhu M, Shao L, He P: Initiating methanogenesis of vegetable waste at low inoculum-to-substrate ratio: Importance of spatial separation. Bioresour Technol 2012, 105:169-173.

32. Lu F, Chang CH, Lee DJ, He PJ, Shao LM, Su A: Dissolved organic matter with multi-peak fluorophores in landfill leachate. Chemosphere 2009, 74:575-582.

33. Yamamoto M, Kurihara I, Kawano S: Late type of daughter cell wall synthesis in one of the Chlorellaceae, Parachlorella kessleri (Chlorophyta, Trebouxiophyceae). Planta 2005, 221:766-775

34. Chen MY, Lee DJ, Tay JH, Show KY: Staining of extracellular polymeric substances and cells in bioaggregates. Appl Microbiol Biotechnol 2007, 75:467-474

35. Qu X, Mazeas L, Vavilin VA, Epissard J, Lemunier M, Mouchel JM, He PJ, Bouchez $\mathrm{T}$ : Combined monitoring of changes in delta $\delta^{13} \mathrm{CH}_{4}$ and archaeal community structure during mesophilic methanization of municipal solid waste. FEMS Microbiol Ecol 2009, 68:236-245.

36. Hammer $\varnothing$, Harper DAT, Ryan PD: PAST: Paleontological statistics software package for education and data analysis. Palaeontol Electron 2001, 4:1-9.

doi:10.1186/1754-6834-6-92

Cite this article as: Lü et al:: Bacterial bioaugmentation for improving methane and hydrogen production from microalgae. Biotechnology for Biofuels 2013 6:92.

\section{Submit your next manuscript to BioMed Central and take full advantage of:}

- Convenient online submission

- Thorough peer review

- No space constraints or color figure charges

- Immediate publication on acceptance

- Inclusion in PubMed, CAS, Scopus and Google Scholar

- Research which is freely available for redistribution
C BioMed Central 